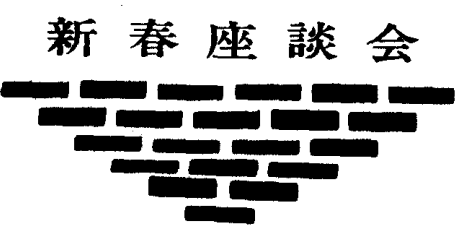

\title{
1970 年代の医科器械の展望
}

一第一線業界関係者を中心に一

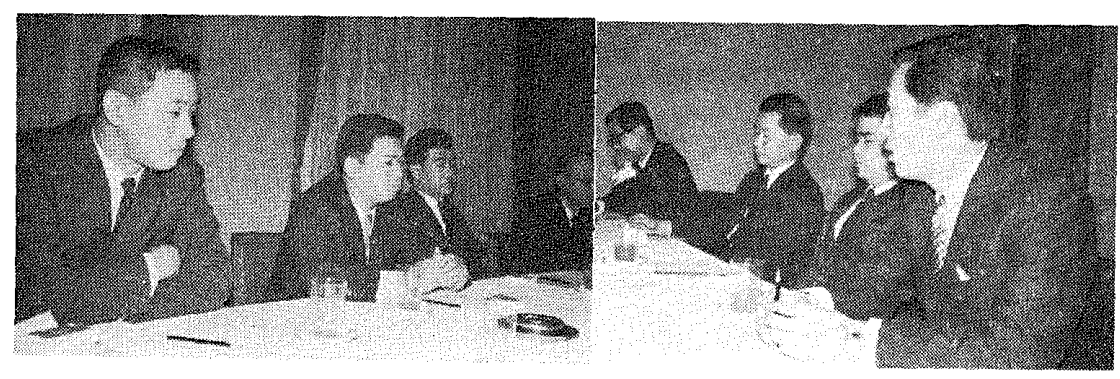

出席 者（順不同・敬称略）

松本 謙一（サクラ精機）

青木 由雄 (泉工医科工業)

根 本 達 (瑞䅹医科工業)

(モブレータ)

古 橋 正 吉 (東京医科藏科大学・手術部)
神野隆司（ナニワ医科工業）

勝 崎 宣夫 (弥生器械店)

西条 恵 路 (武藤器械店)

(司 会)

市 河 鸿 一（市河思誠堂）
市河，本日は第一線で活動されている方々ば かりにお集まり願いました のですが；㧍忙しいところ をおいでいただきまして, たいへんありがとうござい ました。

「1970 年代の医科器珹の

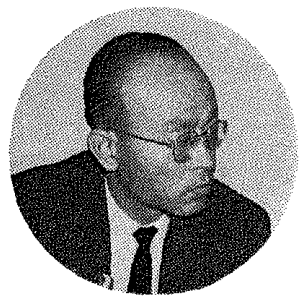

展望」といらような非常に壮大なテーマで,こ の座談会を開かせていただくわけでございます が，まあ新春放談というような意味で，ひとつ 㧍若い皆さん方の言いたい放題のことをしゃべ っていただきまして，ひとつ明るい，希望に溢 れた印象を読者の方々にぜひ植えつけていただ きたいと思います.どうぞあまりテーマにこだ
わることなく，それぞれのお立場で日頃感じら れておりますことを何でもけっこらでございま すからどんどんご発言をいただきたいと思って おります。

先般, 同じテーマで医学関係者 (とくに外科 系）の座談会を催しました。

一応, 先生方のご意見の集約といいますか, 私の感じましたMサイドの先生方の, 今年から の70年代に期待される医科器械とい5ものはど うあるべきかというようなお考えを簡単にお伝 えいたしますと, 要するに従来のいろいろな機 器で, 材質とか工作技術, 処理方法それに使い 方, そらいう面で現在のままでよいのか, それ よりすぐれたものはないかという姿勢をしょっ 
中とってもらいたい，目標としては，だれがや っても確実にできるという器械と方法を確立し てもらいたい、それからまた，ディーラに望ま れることとして，Mサイドのほうでいろいろな クレームとか，希望意見をお伝えになったとき に，ディーラ自身が間違いなくメーカに伝えて ほしいといらよらなこと.それから，この間の 座談会では, 将来の展望といらことが話題に上 がる前に時間がきてしまいましたのですけれど も, 高圧酸素室なども含めまして, 安全基準と か規格化などの問題で，この70年代は相当進む のではないかということ、それから $\mathrm{ME}$ 関俰で は，一応現在の情報キャッチといらことにとど まらず, データ処理, プログラム処理, 患者制御 といらような一つのループで, フィードバック させるような $\mathrm{ME}$ 機器が将来期待されるし，ま たそれに向かってわれわれも努力したいといら ようなお話，そんな内容で, 前回の座談会は話 題が広範囲にひろげられたわけでございます。

\section{欧米の嶪界を見て感ずること}

そこで，きょうは業界の若い世代の方々に集 まっていただいたので，ひとつ国内に限らず， 国際的視野にも立った70年代の医科器械, それ に本日は業界に対する点も含めまして，70年代 の展望というようなテーマで，それぞれのいろ いろなお考えなり，お話なりを承らしていただ きたいと思います。

きょう，ご出席の方々の中には，欧米を比較 的最近ごらんになってこられた方が何人かいら つしゃいますので，ひとつ若い目で見た欧米の 医科器械, もしくは欧米の業界, そういうよう な点を印象でけっこらでございますから，お話 をいただきたいと思います．さっそくですが， 松本さんにまず口火を切っていただきたいと思 いますが・......

松本 まあ，いわゆる放談とおっしゃるの でそのつもりでしゃべら せていただきます．私も海 外へは商用でよく参ります が, 私の場合, 視野の狭 い，あるいは見方が一方的 であるかもしれませんので
一忘ご諒承ください.一般に「医科器械」といっ ても，いわゆる世間一般にいら医科器械，それ からレントゲンを含めた ME関係の機器，それ から光学顕微鏡，ガストロカメラ，そらいった ものも含めた光学系を応用した医科器械，ある いはディスポ製品というようにいろいろに分類 されると思らのですが,それらがおしなべて'70 年代に向って着々と歩み出しているといら感じ だと思います。

济カ化について ○

その一例として，いわゆる省力化というので すが，「人手を省く」という方向に歩一歩と進 んでいるといら気がいたします。これは非常に 大きい方向だと思います。で，その省力化につ いてふれる時に，いわゆるユーザ・サイドで の「器械の使い方」という意味での省力化とい う場合，それからメーカ・サイドで見た場合の 製造工程上の省力化, それからもら一つは流通 経路上での省力化，というようないろいろな角 度から省力化という現象も眺められると思いま す. 第一の「器械の使い方」というか，あるい は器械自体としての省力化といら面で見ていく と，これは私は別の機会にもふれたことがある のですが，2つの方向，あるいは 2 つの現象と して見られます．その一つは「ディスポーザブ ル化」であり，他の一つは「オートメーション 化」であってすでに欧米各国ではそのような方 向で動き出しています．日本でももちろんそう いう方向が既に年々より顕著に出てきているの ではないかという気がするわけです.これはも ちろん予算的な裹づけ，あるいはいろいろな事 情が伴わないと実現できないこともあるかもし れませんけれども，少なくとも日本でもそうい う方向には進み出しているのではないか，ある いはもらかなり進んでいるのではないかと思い ます．ただ，そのような合理化傾向なんです が，これをいわゆる流通経路という角度から見 た場合，いわゆる問屋無用論という論議が以 前, 否いまでも一部の業界では, マスコミ等で とり上げられているのを思い出します．これは 即，日本のわれわれの業界では，あてはまらな い面が多々あると思います，しかし，向こうの 業界，とくにアメリカあたりの業界では医療雑 
貨のようなものになりますと，よく知られてい るように,いわゆる「通信販売」式の形でやられ る場合，あるいはメーカがよろず承ります式の ディーラに任せることは満足せず，直売してい る方法，いろいろあるようです．とくにディー ラの在り方というか，あるいはそういうディー ラ・サイドでの問題が, しばしばとり上げられる ようです．欧米各国，とくにアメリカあたりの 影響を日本の場合非常に強く受け易いと思われ るので,アメリカあたりの行き方を見ますと,と にかく非常にディーラがよく勉強をしている。 先ほど，Mサイドの強い要求として「今後のデ イーラはユーザの要望をメーカに正しく伝える こと」というお話があったことを拉ききしたの ですが，確かに当然のことと思いますし，その ほかに何といらか，ディーラがいわゆる「器械 の正しい使い方」あるいは「そうあるべきであ るという使い方」をよく認識してユーザに販売 する，あるいは説明する，われわれの医科器械 の業界でも，ただハード・ウェアを売るのでは ない,ソフト・ウェアも含めたセールスをす る、いわゆる「システム販売」といらか，そう いう現象が非常に出てきているのではないか. これは器械が高度化するに従って当然出てくる こと上は思いますが，とにかくそういった傾向 が非常に顕著に出てきている。これは，先ほど の第一のディスポーザブルの製品であっても当 然そういう必要性活出てくるのであって，たと えばディスポーザブルの材料に高分子化合物を 使う。そうすると熱に対してどうだろうとか， あるい注その他物理的な条件に対してどのよう な反応京すであ万らかよいうようなことにつ いても，ユーザの使用目的に忍じて，十分納得 のいくようにメ一カを代弁して，説明ができな ければならない，それから非常に高度に「オ一 トメ化」された器械, こらいったものについて は，よりそのようなことが言えると思うのです が，いわ沛るソフト・ウエアについてアメリカ のディーラは非常によく勉強している。 また， そういうことまでも，勉強していないと，われ われの業界でも 1 人前の高給取りのセールスマ ンとして認められないのではないか.ですか ら，ただ単に日米両国の生活水準の違い，ある
いは物価水淮の違いということだけから，両国 のセールスマンの報酬が違うとはこの場合, 一 概にいいきれない上うに思います。これは比較 しての上のことで，むちろん日本の各医科器械 メ一カ，あるい惊ィーラのセールスの方もよ く勉強して扮られるとは思うのですが，はっき りした目的意識をもって，今後もっと，もっ と，そういうシステム販売の勉強を強いられて くるのではないかといら気がするわけです。そ らしないと流通経路上での省力化というより， 省略化，つまりよく勉強するディーラのみが， 生き残るというようなことになってこないとも 限らないと思います。こんなことを，感ずるの ですが，それにつけてもメーカ・サイド，ある いはディーラ・サイドで過当競争がある程度防 止される必要性というか，たとえばアメリカあ たりの業界での一つの製品の製造・販売プロセ スと比べた場合に，日本ではあまりに多くのメ 一カが乱立しているとか，あるいは一つの取引 に対して非常に多くのディーラが殺到するとい うようなことから，適正利益さえも保たれない というようなことですと，なかなか勉強しろと か何とかきれいごとを言ってみてもはじまらな い，つまりそういう余裕が出てこないのではな いかといら気がします。そこら辺はメ一カ・少 イド，あるいはディーラ・サイドについても， いろいろな意味で考えなければならない問題が いろいろあると思います．全般的な方向として は，そのように動いているのではないかという 気がするわけです。

$$
\text { アフターサービス }
$$

市河 ありがとらございましたたいいん理 論的にあちらの状況をごらんになっているよう で，今後の医科器械の発展の見通しというもの が省力化にあるというような点で，私も同感で ございます．とくに最後に強調されたディーラ

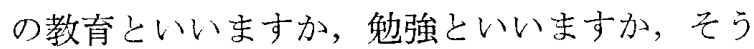
いうものが結局，もっときびしいものになるだ ろうという見通しですが，これは中小企業全般 にわたって言えることだと思うので，われわれ のような医科器械業界といらものの今後ある心゙ き姿というのは，やはりサービスに何としても メリットが置かれるのではないかと思いますの 
で，私も松本さんのご意見に同感する次第でご ざいます，

松本 いまのサービスといらことで，ちょっ とつけ加えさせていただきます、いまのサービ スという言葉で思い出したのですけれども，よ くこれは言われることだと思うのですが，日本 のいわゆる医科器械の場合に, いわゆる無料少 一ビスというのですが，そういう形が非常にい ままで多かったのではないか，という感じを抱 いています。これは他のたとえばエレベータで あるとか，いろいろな機械の場合，有償サービ ス，有償保守契約というか，いわゆる有料专一 ビスです㸚。これがなされているのに，どうし て医科器械の場合，そういうことが今までむず かしかったのかという疑問を同時にもちます。 しかしこれは私どもの会社だけではないと思う のですが，皆さん方のところでも，最近は有料 サービスが徐々にではありますがふえてきてい るのではないかと思います。ただ，これはメー カ・サイド，ディーラ・サイドで一生懸命それ を唱えてみてもだめなんで，ユーザ・サイドで もって，ユーザの方々にそれを正しく認識して いただいて，大いにそういう方向に持っていっ ていただきたいと思います、ただし，その場合 「責任あるサービス」というか，一これはよ く言われることですけれども，「アフターサー ビス」というものだけでなくて，サービスをし なければいけないような，故障が起こる前に， 事前にサービスをする。いわゆる向こうでいわ れる「プリベンティブ・メインテナンス」とい うのですか，そういうようなことがよく言われ ますが，そういう「プレ・サービス」というも のに，より真剣に取組んでいかなけれびいけな いのではないかと思います.アメリカのメー カ，これは私ぶ見たメ一カだけかもしれません けれども，そのメーカの場合，よくそういうサ 一ビスを必要とするような器械を販売するとき に, はっきりと最初から「本体の価格（アフタ 一・サービス料はここに入ります)」プラス「プ レ・サービス料」というような形で契約をする 場合が多いらしいので，そういうようなシステ ムを今後われわれの業界としても，ますます採 り大れていきたいと思います. 私, たまたま昨
年向こうに行ったときに非常にいい本だと思っ て買ってきたんですが，「臨床検查のためのプ ラクティカル・オートメーション」といら分厚 い単行本がありました。これは㧍医者さんが 3 〜 人かかりで書いたもので最新の検查器械だ とか, いろいろな器械が出ている本ですが, そ の第 1 章は別にどの器械のことについて触れた わけのものでもなくて,「エクウィップメント・ メインテナス」という, 要するに器械の保守点 検というか管理といらか，そのようなことにつ いてまず巻頭にもってきている，ということ一 つから見ても非常にユーザ・サイドでも，そう いらサービスといらか, 器械の保守点検サービ スといらことに対して非常に関心が深いのでは ないかという気がしたので, ちょっとつけ加え させいただきました。

市河 まことに抢っしゃるとおりで，いわゆ るわれわれの日本の医科器械といら場合に, ギ ヤランティという問題が非常にあいまい模糊と して，その辺からいまの無償サービスという点 が強要される.こういうように思いますので, そのギャランティという面を明確化するという こと，それをこの70年代にぜひ確立しなければ ならないことだと、私もかねてから考えて打り ますし，非常に大事なことだと思います。とく にいまのサービスといら面では，私も何回か外 国の状況に接しました感じで申し上げますと， メンテナスに関するインストラクションブック などが外国の製品の場合完備している.この点 がどうむ日本で河となく份万そかにされてい る.そういう面でのサービスもディーラ・サー ビスの一部にもなるし，またメ一カ・サービス の一部にもなるのではないかとも思いますの で，ひとつぜひともこの70年代には，われわれ の業界も一人前になるべきだと感じますので, たいへんいい補足をしていただきました.

それでは，次にひとつ青木さんに，やはり外 国の事情に詳しくていらっしゃいますし，また とくにアメリカには長くご滞在になった経験も 拉りり゙すから，ひとつそういら面からごらん いただいた欧米の事情といいますか，また将来 の行き方といったお話をしていただきたいと思 います。 
靖木 すべて松本さんがお話になってしまっ たので，しばらく外国に行 っていない私など話すこと がなくなりました.ただサ ービスのことですが，もっ と日本でもサービス期間を 徹底した一定期間に決めて

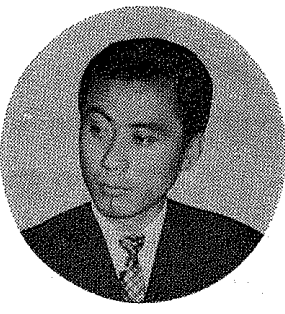
も良いと思います。

アメリカの場合ですと，必ず 1 年なら 1 年の 保証期間というものを立てて，その間の故障, メーカ・サイドのミスの場合は，もちろん無料 保証ですが，その後のものはすべてチャージを 取るといら徽底した制度を採っています，日本 でも，このようにしなくてはいけないと思いま す.

これは別のことですが，この間アメリカの会 社と契約しまして，一番驚いたことは，契約書 をつくるのにアメリカ側は必ずアメリカ人の弁 蓄士を間に入れ，そのアメリカ人の弁護士が日 本にいまして，その方に電話をしたり，また向 こらから資料を送ってもらうときに，必ずそれ に対してのチャージを取る. あとから請求書を 見てびっくりしたのです. 1 回何分かの電話で 話をすると，そのときのチャージがちゃんと請 求書についてきているのですよまあ，そこま でアメリカ的にする必要もないですけれども， 日本もある程度, そういう医科器械のアフター サービスの場合も， 1 年なら 1 年ときめたその あとのチャージというものは取っていいのでは ないかと思います。

\section{医・理工学とメーカの結合 ○}

また，私がアメリカに行って感じたことは， 日本ではまず予算の点で制約があるのでしょう が，あちらの病院は，主任教授が莫大な予算を 黃い，高価な器械を自分の研究室に膡き，自分 の下に各方面のテクニシャンを揃える，たとえ ば，工業電気化学方面のテクニシャンを抱え， 独自のテーマの研究を進め, 学会などに発表し た後に，それを商品化したものをメーカに渡 すそそして，これをメ一カが生産するという非 常に理想的な連慗で羡しい次第です.

国内においても，大学など独自の研究を続け るところもありますが，まだまだ予算の関係
で,アメリカのように豊富な予算で大学独自の 方針で積極的に推し進めて行くことがとても困 難のようです。

市河 ありがとうございました．確かに松本 さんから要領のよい話をしてくださったので， ほとんど真奮をついたというような感じがいた しますが，いまの青木さんのお話の中にもござ いましたように，一つの新しい製品ができてい くプロセスを見ておりますと，欧米諸国の場合 ららやましいものがあると思っております。ア メリカなど歩きますと, 病院でお医者さんが器 械のメ一カの人に対する態度というものは, 非 常にゼントルマンシップで，対等の立場で一緒 に研究しているのだという，ファンデーション のもとにいろいろな会話がなされているという 点がうらやましく感じられます，日本でも最近 そういう傾向がだんだんできてきて，われわれ

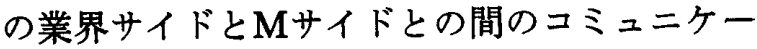
ションというものが非常に円滑になりつつある と思うのですけれども，まだまだそういう意味 で改善の余地は多々あると思います．70年代に ぜひこの器械学会の研究会, あるいは座談会に おけるコミュニケーションを通じて確立してい ただきたいものだと思います。

青木 それからもう一つ気がついたことは， アメリカなどの場合は, 医学部とまたほかの工 業面の部との横の連絡ですね，それが非常によ く組まれて研究しているわけですね，私まだ国 内のほうはよく知りませんけれども，日本のお 医者さん方は，まだ自分たちの医学部だけで研 究を進めているということで，それをもう少し 工学, 電気のほらと横の連絡をつけてわれわれ に指導をしていただければ，もっと日本の器械 も発達するのではないかと思います。

市河 いまいわれたことは私も全く共感を感 じますけれども，Mサイドの座談会でも，阪大 の中島先生がその点を非常に強調なさいまし た、いわゆる医科器械というのはロケット, 宇 宙衛星，ああいったものの開発と共通したシス テムエンジニャリングである.したがってそう いう横の連蘩といいますか, 組織化された医・ 理工学関係とメーカとの手の握り合いというも のが望ましい．そして開発されたものには必ず 
そこにオリジナリティも生まれてくるし，日本 の医科器械というものが出てくるのではないか といらような括がございました. まさしくそ の通りだと思うのでわれわれもそういう意味 で，できるだけ前向きの姿勢で先生方といろい ろな対話を取り交していく，こういう勢で進 むべきだと感じますね.

その点業界サイドでも中高年層の方々のなか にはみずからを門戸を閉ざしておられるような 傾向が非常に強いですから，ぜひわれわれ若い 世代から，ぜひ全面的に開放して，先生方と対 話を続けていきたいものだと思います.

労的密度の充实 ○

それでは根本さん，だいぶ前にいらしたわけ ですが，実際に工場のほうをおやりになってい る立場で，欧米をお手本としなければならない 点, また必ずしもそうでなくとも，望ましいと 思われるような点をひとつお話をいただけませ んでしょうか。

根本 私がアメリカに行きましたのは，だい ぶ以前ですので, よくわか らないのですが, 私が行き まして，そこで感じました ことでございますが, アメ リカは,この業界だけでな く他業界むそうでしょう

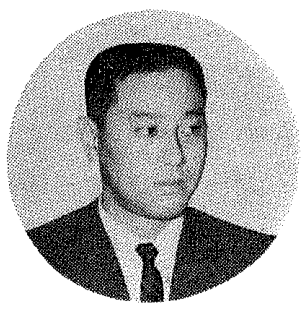
が, 非常に時間に対してきびしい,いわゆるドラ イに割り切ったプロ意識に微底しているという 点でございます．私ども医科器械，とくに製造 部門の場合どうしても良い面でも悪い面でも職 人気倎がまだまだ抜け切れないように感じられ ます. その点, アメリカの場合は時間に非常に らるさい，たとえば朝 8 時から夜 5 時までなら ば，その間は寒に熱心に，たばこも吸わないで 一生愻命やる.お昼もパンをかじりながらやる という，そういうょらなきびしさですね.そう いった, 決められた枠の内で, 各自がその責任 を充分自覚し，作業密度を浱くしていくとい う, きびしさというものを, われわれの業界で も当然採り入れられなければならないのではな いかというように考えるわけです，それが生産 性の向上といったことにつながってくるのでは ないでしょらか. 腕のいい職人さんが長年の年
季でものをつくっていく時代から，機械化によ る品物の均一化ですか, そういった方向に進ん でくるのではなかろらかというように私感じま したのですが.......

市河 ありがとらございました．まさしくそ のとおりでして，欧米というよりもとくにアメ リカはそらですね. 非常に時間に対して厳格で ある.確かに労恸時間は日本より短かい、私な んかこのごろ自分の会社を見てみますと，どう も欧米並みじゃないかと思う場合もあるのです がね. 拘束時間は何時間, 実鮒時閒は何時間な んて計算してみると，どうも週 5 日制と何ら変 わりのないような時間になりつつある.そうい う面で，ただ外面的な，時間の制約を改善して いくといらだけではなくて,やはりその中での 仕事ぶりというものを密にしていくという意味 では, 確かに根本さんのいわれるとおりで, 外 国には学ぶべき点が多いのではないかと思いま す.

ヨーロッパでも，イタリアなどに行きます と,あれは何時からでしたか, 午後シャッターを 締めてしまって, 商店, 事務所などの仕事はま るっきり止まってしまう．私の行ったときは, たしか 4 時まで締めていました. そして 8 時く らいまで仕事をしているのですね. そらいら行 き方が必ずしもずぼらではなく働く時閒はフル に働いているといらような点で考えさせられま す. 日本人は勤魅だと言われて, ついいい気に なっておりますけれども，これからの日本の医 科器械といらものは相当きびしい，外国からの 押し寄せる波にもまれていかなければならない といらことを考えてみますと，単に生活条件が 改善されたことだけを喜んでいますと，いろい ろな問題が将来に牫されてくるという感じがす るのですね. 確かに私もその点, アメリカなど を歩いて見まして感じました一っでございま す. 神野さんは外国へお出掛けになっておりま せんか。

\section{後進国への榆出も前向きで}

神野私は海外の一部, アジアだけしか知り ませんので.......

市河 けっこうです. ひとつその方面はわり 
あい私ども5といものでございますから，あち らの実情とか将来の市場としての可能性とか, そういら面でけっこうですから，お話をいただ けませんでしょうか.

神里私は一昨年11月ごろでしたか，台湾の 医学者に当社の器械を出品 いたしましたので，その機 会を兼机て台湾, 軲国, 沂 繝の3力国を迥ってまいり ました．日数もあまり取れ なかったので充分病院の視

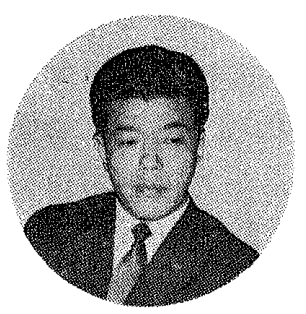

察もできなかったのですが，それでも代表的な 2 -3の病院に出标けて、いろいろな先生方や看 護婦さんともお話をさせていただく機会を得 て, 私の方が関係しております手術室や中央滅 菌材料室また検査室などを見学いたしました が, 器械設備その他の点で, 日本の医学的レベ ルから見ましてかなり遅れているような感じを 受けました。

ただ，私が一番印象に残っておりりすのは， いままで相当数の日本製の器械が入っており, もちろん欧米の製品も随分入っておりました が，過去に入っております日本の製品は非常に 覀いよらに思いました. 現に手術室で見た鋼製 小物などは真赤に銧びていましたし，その他の 医科器械も $2 \cdot 3$ 使用せずに積み重ねてあった 現場を目の前でまざまざと見せつけられたよう なわけでございます.もちろん先生方や, 看讙 骕さんも口をそろえて日本の器械は非常に覀い ということを，しきりにいっておられたことを おぼえております，ただし幛国の場合などは，

一般的に対日感情が悪いといら条件がございま すし，予算の点などいろいろ問題があるように 思いますが，台湾にしても䡟国にしても医療面 でのレベルが非常に低く，今後の大切なマーケ ットになると思いますし，信用を取り戻すこと がまず先決問題であると思います，と同時にわ れわれはもっと輸出といら問題にも真剣に取り 租んで勉強しなければならないと思います。

青木 それはあれですか，日本のメーカの銅 製小物ですか。

神里 そらですね，破かに日本のメーカのも のです.たたしこれらの粗悪品は現在の有名
なメーカの製品とは違うように思いました。ネ 一ムの刻印も私たちが全然知らないよらな製品 でした．またネームが入っていない非良心的な 製品も見受けられました。ただ私が感じました ところでは，おそらくこれらの製品は予算にし ばられて医科器械の専門業者の手で輸出された ものでなく，いわゆる一般の現地の貿易業者の 手から納入されたものではないかと思います. また，いままで入っております器楲は大へん古 いものが多いよ5です. 正直申しましてただい ま説明させていただいたよ5な状況で本当はが っかりさせられて帰ってきたよらなわけです. しかし，あかるいニュースもありまして，最近 あちらで行なわれております医学会に相当日本 の有名メ一カの優秀な製品が展示されており， 業者間では代理店契約などが稘極的にかわされ ている状態で今後は非常にあかるい見通しが持 てるよらに思いました.もちろん後進国ですか ら器械の購入も，これからだと思いますが,こ の機会に医療業界がとくに輸出に対して䅡極的 な姿勢で対処すべきだと強く感じました.

市河 碓かに輸出されている医科器械という ものが，いわゆる日本でもメ一カと称する相当 確固たる基艋に立った業者の製品でない場合が 多いのでいまおっしゃったよらな品倎の粗悪 というようなことが出ているのではないかと思 います。

赤木 私もそう思います。

市河 ただそれで，われわれに責任がないと いうことにはなりませんので，やはり今後おそ らく東南アジアに限らず，いろいろと日本の医 科器械とい5ものが海外に伸びていく可能性と いうものは非常に多いのではないか. そういら ように考えますと, 品犋管理, またサプライヤ 一の方々の㒛識, 值段で競争さえすればいいと いらものではない.これはおそらくいまお話い ただいた 4 人の方々, 皆さんお感じになったこ とだと思らのですが，一歩日本を離れてあちら 側から日本を眺めた場合の日本といら国に対す るものの感じ方といらのは, 確かに非常に睘国 的になる. そらいら意味からいっても，そ5い 5国家的な立場から考えてみて，も5少し良心 的な立場で物の供給といらものを考えていただ 
かなければならないのではないか，そういう感 じがいたしますね．確かに本梊的には先般のM サイドの方々のお話の中にも材椞の管理だとか いろいろな表面処理とか，そういう間題で，ま だまだ欧米に届かない点は多々あるということ は，すでにご指揞をいただいておりますけれど も，単にそれだけではないという感じもいたし ますので，これはひとつ輸出を業となさってい るような莱界の方々，それからまた，業界にほ とんど無開連の方がそらいう侖出をなさるとい ら場合には留意していただきたいことです．ほ かの日用品と倳いまして，検查機橉というもの があまり確立されていないわけです．したがっ て，形さえあれば，值段さえ安ければ輸出され るといら感じもないでもないと思いますので, その辺のチェック機褠といいますか, 普通の商 品は全部輸出検查というものがあるわけです が, 医科器栈に限ってどうも何とはなしに出て いってしまらといらケースが多いので，いまお っしゃったような結果が方々で見受けられるの ではないか，こう思います。

\section{無视できない日本の商伀翼}

それでは一応皆さん方，若い目でごらんいた

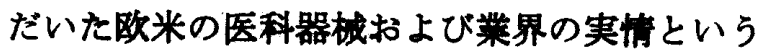
よらな点をお話いただいたわけですが，ひとつ ここで話題を展開いたしまして，70年代の業 界，それからまた先生方を含めたユーザ・サイ ドに何を望み，何を期待するかというようなこ とで,ひとつ旨さん方の活発なご発亩を期待し たいと思うのですが，勝崎さんからそういうテ ーマでお話をしてみていただきたいと思いま す.

畹崎 いま外国における日本の立場，また諸 外国の商慣習そういうよう なものを外国に行かれた方 々からお開きしたのですけ れども，お閏きしていて， 確かにそれは採り入れなけ ればいけないといら問題た

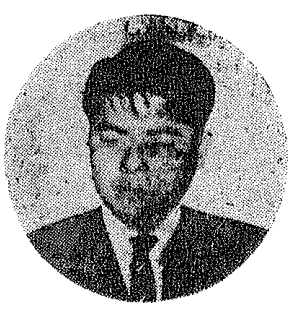
くさんあると思います．しかし日本には日本の 気候, 風土があるように日本には日本の商慣習 があると思いますが，それに合ったもの，また
非常にすぐれておると思うものは当然採り入れ なければならないと思います。

アフターサービスの問題も松本さんからお話 がありましたし，市河さんからもご説明いただ きましたけれども，非常にユーザから無理な注 文が多い.アフターサービス即無料修理である と思っておられるのではないでしょうか。それ で私は，よく医科器柀そのものでなくて，ほか のものを対象にして先生方にご説明申し上げる のですが，とくに自㲜車の場合，いわゆる運転 ミスによってぶつけたものは当然，自分が修理 代を支払っておられるではないですか．また， いま問題になっております久陷車の場合には， メーカのほうが責任を持って直しているではあ りませんか. それと同しことで医科器械にも同 じことが震えるのですからといらことで説明し て納得していただいています。ですから䬽明の 方法といらか，われわれの持って行き方が悪か ったのではないか，それをも5少し微底して真 のアフターサービスといらことをやっていきた いと思っております。

それからまた，渝出業務といらお話をお開き していたんですが，礁かに倫出といらことで外 货の塔得であるとか，その他もろむろの間題が ありましょらけれども，われわれのところにも よく照会があるのですが，これは㻌出価格です からというようなことで, 特別な值段を出され ている. 当然値段的な差があれば, 商品は差が 出てくることもあると思います．その辺付，絶 対に商品に自信があるものであれば，值段はそ ら心配することはないのではないかとい5気が します。とくに私のほ5は内視鏡といらものを やっておるのですけれども, そういらものに対 しては，われわれ自信を持っておこたえをして おりますし，商品そのものに自信を持っておれ ば，何もコストダウンした輸出価格といらよう な特別な值段で出す必要は, まずないといら気 がします。

それからユーザのほらからメーカの方への希 望, 要望条件の伝達方法ですが, 先生方のご希 望が, ディーラのほうからメーカのほらに正し く通っていないのではないかといらことは, 確 かにそらいらことは私ども殸めますが。そのよ 
うな問題を解決するには，われわれの業界とし てもやはり専門化して，それで，その部門の心゙ テランをユーザの方にお伺いさせる，たとえば 外科の器械であるのに眼科の担当の者がいって も喰い違いが起こり得る場合もあります。ま たそういう可能性が多いと思います。ですから 同じ病院に, 専門の者が婦人科は婦人科, 外科 は外科というように，ダブっていってもしよう がないので注ないか，それで二度三度足を運ぶ よりも，一度で話がスムーズに通るような方法 をこちらもとりたいという希望を持っておりま す.

それから器械の簡易化ですとか, 省力化とい うようなお話も出ておりましたが，その前にメ 一力側としての顡いなのですが，われわれ が, 器械の検収を受ける場合, また使用説明を する場合，先生方とディーラの方と一緒に立ち 会ってやっているのですけれども，そのときは ディーラの方とそれからユーザの方との両者に ご説明申し上げているのですけれども，何か先 生方のほうでも熱心にノ一トをとっておられる 先生と, それから比較的不熱心な先生と非常に その差が激しいのではないかと思らのです。そ れで一応, これでよろし泌うございます权と言 って戻ってくるのですが，日を改めて，2，3日 後にまた説明してほしいというようなことが非 常に多いのです. ですからその辺のことも，わ れわれも一生懸命説明して納得していただこう といら努力をして抢りますのですから，そうい ら場合にや法り先生方にノートをとっていただ くような熱心さを示していただきたいと思いま す. 熱心さと不熱心さの差が操作ミスによる器 械の故障につながってきますので，十分気をつ けて聞いていただきたいと思います。これはお 願いなのです.

それにわれわれは地方に出張していくのです けれども，そういうようなときに地方の特約 店, 代理店の人と同行して病院へ抢伺いするの ですが, そちらのほうの方も, 自分は自分の仕 事をしている場合が多いようですが，一緒に聞 いて，一緒に魅強をしていただきたいという希 望を持って抢ります．何かまとまりのないよう な話となったのですけれども，こういうような
希望的，またお願いということで結んでおきた いと思います。

市河 ありがとらございました，確かにその ユーザの先生方からのいろいろなご注文という ものが，医科器械であるからということで，一 般常識からだいぶ外れた要求をされるという場

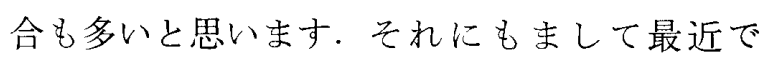
は, 安全対策という点では考え方がどんどん進 歩してきて抢りまして，たとえば最近問題にな りつつある高圧酸素室の安全基準とか，ああい うものにも使用基準といらものがちゃんと折り こまれているといら点もございますので，おそ らくこれは70年代には, そういう面での改善と いらか，これは医療過誤といら問題が，抢そら く今後10年間には日本でも相当やかましいこと になる.こういら点から，いわゆるメンテナス に対するいろいろな責任の所在というようなこ とが明確化されてくるという感じがいたしま 于.

それから商品に関して, 確かに町田さんのつ くられている内視鏡というのは, 世界的には誇 りに足る商品でございます. そういうものであ れば，あまりコストとか，そういうものを考慮 する必要はないのではないか，こういうご説も 至極ごもっともで，そういう商品を持ちたいも のだというように私も感じますけれども, ただ 私, 常々感じておりますのは, 最近のたとえば 鋼製小物のような製品が，ごく最近はあまりな いようですけれども，近年急激なコストアップ をされている．この辺はひとつ70年代にはぜひ 反省をする必要がある、私沈乞ら考えます、単 に生活改善だけを目的とする，むしくは人手不 足を解決するというだけの目的のために, 国際 的な一つの標準から外れたような值上げは上ほ ど考え直さなけ机ばいけないのではないか、い ろいろな面で, さっき根本さんの抢話にもござ いましたようなきびしい作業時間の密度の充実 というようなことで，もっと考え直す点が多々 あるんじゃないかというような気もいたしま す。

\section{地方業者の立場から}

ひとつ今度は, 北海道で非常に大きなシェア 
を持ちになっていろいろなディーラもしくは サプライヤーという立場で扔仕事をなさってお ります西条さんのほうから，ひとつ抢話をいた だきたいと思います.

西条 ただいま皆さん方のディーラに対する いろいろな要求, あるいは 吹米を回ってこられた方々 のディーラに対する役割り というようなことについて も，われわれも考えさせら れる問題が相当あると思い

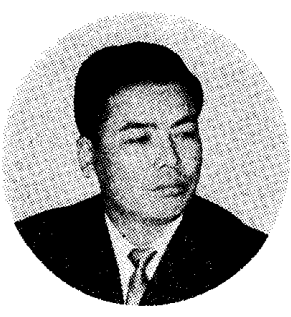
ます。ただ，ディーラのほうから言わせていた だきます，と先注ど松本さんから扔話がありま した問屋無用論, こういうものについてはわれ われも非常に関心を持って抢りまして，メ一力 とディーラ，それからユーザというような一本 化して何んらかの線が，今後われわれに必要で はないかといら気がいたします。

それからユーザに対してですが，われわ机は とにかく先生方から要求があったことを正確に メーカに伝えるといらのは第一の役目だと思っ ておりますが，何せ相当機種を扱っております 関係上，まあ不適格なものがあったのではない かと反省する次第でございます.

私，全国のシェアは知りませんので，北海道 に限って話を申し上げるわけでございますが， 北海道というところは，とにかく海を一つ渡り ますので, 非常に地理的, あるい:気象条件, それから産業発展率というものが低いわけでご ざいますそそういうことで物価のほうも学会並 びに皆さん方がこうやって推まりいただいて しゃべっていただいたわけですが，先生方も当 然学会あるい性展示会などで大いに勉強してい ただいているわけですけれども，メ一カの方々 が展示会だけでなく，北海道にどんどんと新し いものを持ってきていただくこういうことに よりまして先生方に満足していただける製品が できるのではないかというように感じて㧍りま す。われわれる新製品，あるい牥ちょっとした 小物でございますが，ユーザから頼まれてもど このメーカへ持っていったらいいのかというこ とをしばしば考えるわけでございますが，実際 心は北海道という立場から，物を持っていって
も，なかなかそれを手がけてくれないというの が実情でございまして，頭の痛い問題だという ように感じております。

市河 㐫りがとうございました. 地方ディー ラとしての拉立場の上から切実に普段感じてお られること，とくに北海道といら遠隔の地にお られますと，いろいろこらしてくれれば，もっ ともっと普及寸るのにとかいうことを捻感じに なることが多いのではないかと思います。ま た，そういう遠隔の地であ机ばあるほどメ一カ とディーラというものが直結した一つのコミュ ニケーション機構といいますか，そういうもの が必要かと私も思いますし，また将来そうある べきだというように感じます。

\section{大阪と東京の業界の違い}

ちょっと抢立場が違うと思うのですが，神野 さんにひとつ大阪という，また東京と違った二 ェアンスの土地で，いろいろ製造をおやりにな っているご体験の上から，この業界なり，また 東京なり，あるいはユーザの先生方にどういう ことを期待されたいがお話をいただきたいと思 うのですが…....

神野 ただいま市河さんから東京と大阪の二 ュアンスの違いについて打話がありましたが， 日本の医療業界全体として大きく見ますと，東 京だから大阪だからといった違い，ハンディが あるといらことは決して好ましい現状ではない と思うのです．大きく日本全体の医療業界の統 一ということは今後の努力に負うことを期待し まして，実際問題として私が感じております大 ざっぱな違いを申し上げますと，先ず業者数の 上から相当の開きがある点です.

これが先ず一番大きな点でこれがあら栖面 での根本をなしていると思いますが，ディーラ ・サイドの方は中間的な橋渡しという点であま り性格的には大差ないと思います。 しかしメ一 カ・サイドになりますとやはりいろんな面で相 当の開きがあり, 私ども日常遭遇している難点 も多々あるようです．たとえばメ一力数が非常 に少く，その点からも業界自体こじんまりとし ていてスケールの大きさに久ける点, 大きな発 展・改良のために酒一段と大きな努力がなされ 
(40)

なければならないことです，実際面では製品の 専門化製作がしにくく必然的に多種目製作に追 い込まれ，外注関係工場，協力工場の選定に頭 を痛めています。医療器械専門の協力工場がな かなかありませんので他業界に頼らなければな らない点，われわれが常日ごろからいい製品を 統一化された優れた製品をと思っておりまして も，相当数の余分な手間がかかり苦労しており ます。しかし，数の大小が即製品の優劣には必 ずしも比例しませんので，われわれはかえって そのハンディを少数精鋭主義をモットーにした 意欲で実際出来上がった製品はどこにも負けな いエンド・ユーザに満足を与える優れた製品で あると自負しています。マーケットにしまして も大阪勢は地の利を生かしてどしどし製品を送 り込んで開拓していくつもりです.

\section{ユーザのセクショナリズムについて}

東京と大阪の違いは，先ずこれくらいにして この場を㧍借りしましてエンド・ユーザでもあ るドクター・サイドに挍願いしたいことがござ います。

一つの製品を作る場合，メ一カはドクター・ サイドには大なり小なりの器械の指導, 助言を 受け試作して，独自の立場でそれの商品化に努 めているのですが，せっかくドクター・サイ ド，メーカ・サイドのカを結集した新製品がこ れは優秀だと折紙つきで完成しましてもドクタ 一・サイドの系列といら名の関所に引っかかり ますと，同じ製品でも A病院では非常に優秀で あると喜んでご使用いただき，また $\mathrm{B}$ 病院では これは○○大学系の器械だから使えないとシャ ットアウトをくら始末です. 昔ながらの封建制 度の名残りが未だに根強く残っているようです 数。小さい日本の国の中で派閥に固執して大き な目でながめて医療業界，また，医薬界の進展 に目かくし同然の状態は今後の貿易自由化に備 え国内でも一丸となって国際競走に参加しなけ ればならない点を考えすすと，一刻も早く取り 除いていただきたいと思います。

幸いにして，最近では日本医科器械学会の主 催で綜合的な研究会, たとえば滅菌法研究会, 麻酔器，鋼製小物研究会などが開かれ，ドクタ
一・サイドから種々の面で指導していただき， 学術的にもメーカ・サイドは大いに啓発され て，これを消化して商品化，あるいは製品の高 度化に努められますことは大へん結構だと思っ ています、各メ一力む研究会を利用して拉互い の進んでいる面, 困っている面を発表しあって 本当にエンド・ユーザの求める器械性能の向上 や，規格を見出すのがメーカのニーザに対する 良心と責任だと思います。

また先の海外から帰られた先生から拈聞きし た話なのですが，アメリカの一流メ一カなどは 会社内部に何人かのドクター, 経験豊かなナー スも勤務して扮り会社内部の共同研究会を持 ち, 器械を実際に使用する者をた器械を作る側 の者が，なっとくの行くまでディスカッション をしてその成果を製品完成に盛り込むという， まあこれ注わが国ではなかなかま致の出来ない 点を含んで拈りますが，まことにうらやましい メーカの理想的な状態なのですが，わが国で もメーカだけの製品でなく，そうした綜合的な 研究機関を通した上に作られた製品をエンド・ ユーザに供するよらにすべきだと思います，万 国博のテーマの人類の進歩と調和伒あると打 り，人閒が月にまで到達するほど, 科学が進歩 した現在, 余りにコンピュータ化, 省力化され すぎた反動として人類，人間を大切にする風潮 が起こってきて抢ります. 政府も基本政策の一 つとして人間尊重に関連する，またその必要な 産業部門，たとえばめざましい発達の工業部門 に附随して起こってきた公害問題それを防止す るに必要な業種部門, また住宅産業, 医療・医 薬業界部門，とくに近来は医療衛生部門もこの 目まぐるしく移動, 進歩する世の中に対応しめ ざましい発達を遂げたよらに思います。

いま盛儿にいわれております，予防医学，院 内感染防止問題, また複雑・多種化しますます ふえた新しい病気に対処するドクター，ナース の数は反比例して少なくなってきて人手不足の 現状です。これを助け補助する意味でのたとえ ばディスポーザブル化された諸用具, 省力医療 器械など，まだまだ勉強する問題はいろいるあ りメーカもらからかしてはいられないと肝に 銘ずる次第でございます．国際的にも日本は基 
幹産業の大部分は欧米諸国並みに先進国の水準 にあると自負しているのですが，まだまだ海外 諸国に学ぶべき点は多々ありまして, 海外製品 のすぐれた特性はどんどん積極的に採り入れ， また綜合的研究の上に立って日本独自の独創的 な優秀な製品を作り出し, 実際問題として欧米 医療器械製品と比べて何ら遜色なしといわれる 製品，また信用を得ること等々，われわれに課 せられた問題は枚挙のいとまのないほど多くあ ります放. 国際線上に出しても決して恥じない 製品, これもオリジナリティに富んだものであ れば，なお結構なのですがいままでの海外の信 用度が日本の製品には余りなかったように思わ れますので一朝にはならずと思いますが，医療 器業界にたずさわる方々の一層の奮起を扮願い したいと思って打ります。

\section{国際学会での発表を積極的に}

青木 ユーザに扔願いといいますか，メーカ として来年からぜひひとつそういう努力をして もらいたいということなんですけれども，日本 の医学というものは, それほどほかの東南アジ アとかヨーロッパ，アメリカと総合的に比較し た場合，私は抢くれていないと思います。また 医療器械の品質だとか, 先ほど神野さんから, さびがあったとかいう括話があったのですが， 中にはそういうのもあるでしょらけれども，一 般的な器械はそれほど扔くれていないと思いま す.そういうものを開発して，先生方にいるい ろ指導していただいて，新しいものをわれわれ メーカが製造しているのですけれども，日本の 打医者さんは外国に行きまして，そういう特殊 な器械, まあいいものがたくさんあると思うの です. そういう器械を使った学問的発表, そう いうものをどんどん外国の学会に行って発表す るということをやっていただく，かなりの打医 者さんが每年々ヶ学会に出席しておら扎るよう ですけれども, 自分の文献とか, そういら器械 のいろいろなものを発表している方が非常に少 ないのではないかと思います. 語学のハンディ キャップといらものもあるでしょうけれども， それをもっとああいう世界中の人が集まる場所 に行って，いろいろ日本のそういう器械のテク
ニック的なことだとかを発表していただけれ ば，外国の方は非常に文献とかそういうものを 重んじて抢りますのでメーカのほうも非常に 助かるのじゃないかと思います。

市河 確かにそういう点が，いまの日本の相 当多数の先生方が外国で開かれます国際学会に 出席して抢られるようですけれども，あまり日 本の医用機器について紹介の労をとられるとい らケースは少ないようですね.これは今後ぜひ お願いしたいことだと思います。

私，それに合わせて感じますことは，国内で いつも欧米各国がうらやましいなあと思います のは, 欧米のメーカはマーケットリサーチをす る場合, 非常に端的に将来の予測が立てられる ということです。こ机は日本ではたいへんむず かしいのです敉. 要するに, もちろん悪いも のそれから少しもそこにオリジナリティもなし で, 特色のないもの，これはやむを得ませんけ れども，すぐれたオリジナリティを持っている もの，またきわだって品質のすぐれているもの こういうものを双手をあげて歓迎するという姿 勢がどうも日本には足りないのではないかとい ら気がいたします。この間集まっていただきま したような若い層の先生方にはほとんどなくな ってきているように思うのですが，まだまだ医 学界そのもののセクショナリズムといいます か，そういうものが災いして，いいものはいい というフランクな判定というものがなされない 傾向がまだ相当あるような気がいたします。そ の面はひとつユーザ・サイドの先生方に品質・ 機構などですぐれているものは，どんどん採り 入れていただくといらような姿勢をとっていた だきをすと，拉とくその製品に対する生産工 程の立て方やコストの立て方などの面で，メ一 カ・サイドの見通しとプラニングがだいぶ違っ てくるのではないか，こういう感じがします。

どうも私の司会が準備不行届で, いろいろ話 題があちこちと飛んだと思うのですが，いまま でのことを拈聞きになってみて，ひとつ古橋先 生のほうで何か扮感じになったこと, また，わ れわれの側ではこういうことを希望するのだと いらようなことをひとつお話いただけませんで しょうか。 


\section{外来科学とコピーの問題}

神野 もう一言，先ほどのつづきになるので すが，大阪から東京の業界を見ますと，やはり 新製品の出現が非常に多い上うに思います，私 たちはいつもカタログによってこのことを知ら され，ずいぶんいろいろと勉強させていただく 機会が多いのですが，ところが，たまたま外国 のカタログを見ていて，性能も，デザインもま ったく東京の製品と同じ製品があることによく 気がつきま寸。私，ある外国人から日本人はコ ピー・ピープルであると聞かされたこともあり ますが，外国の良いところは，大いに見習うべ きで進んだ面はできるだけ採り入れる必要はあ ります。，小さな島国の日本にくらべて，諸外国 は無限に広い知識の宝庫のようなものですから どしどし積極的に採り入れることは，大いに結 構だと思います．しかし全面的に猿ま的な的な採 り入れ方に問題があると思うですが，話がちょ っとはずれて申しわけありませんが，たとえば 時計，カメラ，ラジオなどは 20 年前までは国内 の事情にもよったのですが，後進国並みの状態 でした，けれども今日では立派にカメラは本場 のドイツをしのぐとさえいわれ，ラジオはアメ リカへもどんどん輸出されておりますし，時計 もいままではスイスの独壇場のようにいわれた のが，オリンピックで使用されたりして，その 品質は国際的にも決してひけを取るものではあ りません．これもここまで来るの纪要した業界 の人々の苦労, 研究の積み重㱛は並々なら好 のがあり，また海外製品の研究などがあったと 思いますが，海外製品そのままのコピーに終っ たならば，今日のような国際的にも高く評価さ れる秀れた製品にまではならなかったと思うの です．東京のメ一カの方を例に出して申しわけ なかったのですが，これは業界全体の姿勢とし てもっと真剣に取り組んでいただきたい問題で すね.

市河 確かにその辺のことは，われわれ若い 層の連中に限らず，この業界の持っている宿命 みたいな形でなおいまだに続いているわけです が，私，宿命と申し上げましたのは，医学とい うものがある程度外来科学である。そう申しま
すと先生方にしかられるかもしれませんけれよ゙ も，われわれ第一線に出て歩いておりまして， 先生方からあるサゼスションを与えられるとい うときに，必ず持ってこられるの汒外国文献な んです叔.こういうのがドィッでできたのだけ れども，お前どうだ，つくらないか。 そういう 辺に開発の一つのポイントが置かれるというと ころにどうしてもそういうことが避けられない という宿命みたいなものがあるわけです，乙か しいつまでもそういう状態では，さっき言わ礼 たようにドィツに勝ったカメラ業界とか，世界 第 2 位といわ机る自動車業界のように，世界を 市場とするというような夢の実現ができないの ではないかという気がいたします。

\section{鋼製小物つ規格化について}

青木 私もそういうことをずいぶん前からい ろいろ感じているのですけれども，鋼製小物類 は，最近パキスタンあたりもここの $5 \cdot 6$ 年前か ら製造し始めて，それがとても安い，その值段 の差額というものは国民所得からきていると思 いますが，日本の大体平均所得が 3 万 6 千円だ と，韓国と台湾が 1 万 6 千円，パキスタンやタ イあたりが 8 千円くらいです上，その差がどう しても，ああいう後進国のものの洒格と比較し てその差が出てきているのですけれども，4年 くらい前にパキスタンの方が扮見えになったと きは，市河さんもご存じだと思いますが，たい

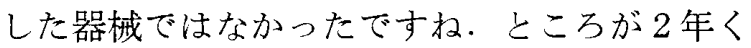
らい前にきたときには非常にそれが進歩してい るのですよそそして，かつ価格も安い，それを 見たときに，われわれも非常な恐怖感を抱きま して，これはあと 5 年， 6 年たったら，もっと 発達していい器械が日本に入ってくるのではな いか。われわれはこれからどうしたらああいう ものに対抗できるか．結論としては結局，日本 として恃殊ないいものをつくる. 同じもので も人のま㸚でなく，かつ進歩していいものか. ほんとうに特殊性のあるものが，同じものでも うんといいもの，向こうの技術ではできないよ うなものをつくっていかなければいかないので はないかと，つくづく思っているのです．また 最近，私ビもドイツから輸入しておりますけれ 
ども，価格の点においても非常に日本の価格と もら変わりなく輸入できるものが最近子えてき たよらです.そらいら点でわれわれの業界とし てもこれから考えていかなければならないと思 らのですけれども……

根本 いま神野さん，青木さんのお話にあり ましたように，とくに鋼製小物類がそうなんで すが，規格化の問題で，寸法にしろ仕様にし ろ, ある程度のものは決まっていると思うので すが，それがなかなか守られない，そういった ものを整理して，できるだけ種類をしぼってい くということをしていただければ，製造する場 合に拈いてある程度の機珹化はできる。したが って均一の安い品物ができてくるということに なるのではないでしょらか.たとえば自動車だ とかテレビ，トランジスターラジオ，何を見ま しても，消費者はオーダ・メードでつくる場合 非常に高くなってくる，それが医療機械です と，それほど迋わないのが現状です，私は医学 のことはわかりませんが，たとえば鎙子類の曲 がり角度がどれくらい倳らとどらなるかかかり ませんですけれども，多少のところで我慢ので きる䇚囲があるならば，なるべ種類をしぼっ て，数をまとめて生産をしていくということ が，やはりいまのお話のパキスタンのもの，あ るいは外国のものに打ち勝っていく一つの道に なるのではなかろらかといらように涍るので すが，われわれメーカの立場と抒使いになる先 生方の立場がございますでしょ5が，それをな るべくいろいろ話し合って規格をしぼっていく ということが何としても急務だと思うのです.

それともら一つ，使いになる先生方と，っく るわれわれとの情報，コミュニケーションの度 合いですが，これはまだまだ足りないといらこ とから，いま神野さんから，「メリカではとい うお話がございましたが，積極的にひとつお使 いになる先生方もわれわれの業界に飛び込んで いただく，そして研究機関を持ってお互いに研 究していけたら，すばらしいと考えます。もち ろんこの場合われわれも先生方の良きパートナ 一となれるよう勉強を重ねなければならないこ とはいらまでもありませんが.

さらに新春放锬ですから，一つのこれは夢で
すが，将来，業界の附属病院でもできるならば 大へんすばらしいですね.

市河 ありがとらございました．おっしゃる とおりで結局，現在の多種少量ということにお 話は通ずると思らのですが，それが一方には， 学会のセクショナリズム，他方にはわれわれ自 賞のなさ，そらいうものから発して過去におい てはずっと積み上げられてきてしまったとい らように感じますので，メ一カ自体としては, 社内的には先ほどのいろいろな生産性の向上と いうことに努力なさるのは当然のことだと思い ます，その反面，やはりいいものはいい，それ からこれでいいんだといら，一つの個人的趣味 でなくて，とかく日本の過去のお医者さんの使 われる器械にはそれが非常に多かったと思うの ですが，その辺を整理していかないと，確かに この断絶の時代ということがよく官われており ますが，いまの大学紛争, 医学部の紛争などに よって，おのずからその辺を整理していただけ るのではないかと私はたいへん期待を持って眺 めているわけですが，あとでまた松本さんにも お話をいただくといらことにしまして，話を持 ちかけて中断して申しわけなかったのですが， ひとつ古橋先生から……

\section{触迎できない冠名改良}

古棈 いまちょうど面白いお話が出たのです が,「手術器械の規格化」の 問題なのです．これは手術 にタッチする私どもとして も，ぜひ実行しなければな らない問題ではないかと思 います，と申しますのは，

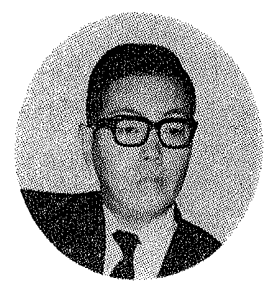
手術の前日にナース，あるいはオーダリが手術 器械のセッティングをするわけですが，これが 何10種類にもなるわけです。で，一度私もその 手術にはたしてその器械が何回くらい使われ て，しかも有効に使われていたかいなかったか チェックしたことがあるのです、その結果, 実 際に使った器械は用意したものの半分ですね. 半分だということは，あとの半分は何かという と，そういう術式になるかもしれないといら予 想，つまり手術が拡大されるかもしれない，縮 
(44)

小でなく拡大ですね。厚の場合に使われる手術 器械がたくさんあるということですね. それか らもら一つは，自分が手なれて，どうしてもそ れがないと，何か手術がうまくいかない，そう いう日常性みたいなものですね。それが一つあ るわけです。医者としての長い間の教育，ある いは実際に手術に当たってきた経験の中にそう いらものがこびりつくことがあると思うのです 叔、それがあるわけです。

それから先ほどちょっと話が出ましたけれど も, 手術器械の中に, たとえていうとケリーの 錬子の先がちょっとつよく曲げて作ってもらう と人の名前がついてしまう。しかも日本人の名 前に変えてしまうという．名前を残そうという 奇妙な「くせ」がはやることがあります、いま でもそう願っている医師がいるかもしれません けれども，これはひとつそういうことは医師の ほうで捨てていただいて，植物や昆虫の新しい 品種を発見するのとはわけがちがうのですか らちょっと角度が曲がる程度で名前が変わると いうことは，種目がそれだけふえることになっ て，器械をそろえるときに，○○式鎮子とかケ リーとか言われたときに，名前の統一ができな い，それは非常に困るわけですね。そうする と，角度幾らということを言抢うとしても，針 のわん曲と違いますので，その表現，あるいは 規格化ができない一つの大きな险路となってい る.ですからメーカとしては，そういうものを 試作する場合には，何々式というものを名乗ら せないよらにするか，あるいは拒否をしていた だきたい，製作拒否ですね。それをやっていた だいて，現在あるもので，これで十分いけるか ごうかご検討をいただいた上で，それでご返事 をいただきたい，たいていそれで凨みますよ。 いま規格化の問題があるので，冠名改良はあま り歓迎できないと思っているのです. 外科手術 は, やはり切って, 縫って, 結んで, そうして つなぐといら基本動作がどの手術の場合にも, これは高度の脳外科においても, あるいは心臓 の移植手術においても繰り返されるわけであり ますから，それに使われる器具というものは， そう多種のものは必要ない, そう思います。た だし材質が進歩したり改良されるといらこと
は，これは歓迎すべきことであるし，それから 低温滅菌など手段が変われば, 当然そういう材 質が新しい適応性を持たせるということが必要 だろうと思いますので，この面の考慮は材質の 進歩につながると思います。

\section{海外へのPRについて}

さっきの打話で輸出したものに，さびたもの が出たというのですが，これは日本でも最近ま で鋼製小物はけっこうさびていたのです．最近 ここ数年，いままでのものほほとんど払拭され て，ステンレスが採用されてから，さびという 問題は，まずなくなってきた。したがって1970 年代は，このような国辱はできるだけ払拭する ようにメーカの方々も努力していただきたい，

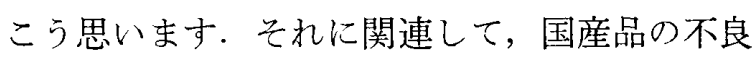
品をチェックする機関というものをぜひ設ける べきではないか.これは市河さんがさっきお話 になっておりましたけれども，海外での日本の メーカに対する認識不足ということもあります ね.たまたま安からら悪かららといらものに飛 びっいてしまったといらことが原因だったとい うこともあると思いますが，これまた医科器械 学会を中心に業界のP Rが不足しているという ことも言えるのではないでしょらか.したがっ て, 医科器械学会も諸外国と連熬感を持つとい うこと，このためにもっと具体的なプランや問 題提起を新年度には持つといらことが必要では ないかと思います。

さっき日本の医者は，アメリカなどに行って 業績を発表していないということなんですけれ ぞも，論文発表法非常に多いのですけれども， 確かに手術器械についてのオリジナルを発表す るといらことが事実いままで少なかったように 思います。ただし麻醉関係の医師らは積極的に 器具の発表をしております.かなり名前の知ら れているのもあります。しかしながら，それは あくまで一人でつくるものでなく，メーカの方 々と協力してつくられていくものでありますの で，共同で発表するとよいと思います，しかし 日本は日本なりに，そういう発表の場を積極的 に持ってやるべきだと思いますが，医科器械学 雑誌がオリジナルに対して英文の抄録を要求し 
ているのですが，あれが非常にいいんです，外 国の人が読んでいて，そうしてお前，勉強にこ いということで留学した事例もあるのです。で すから私は, 一歩を進めて, すぐれた器具の考 案であるとか，改良の発表であるとか，あるい はメ一カの発表です叔。これは医科器械学会の 肝入りで雑誌の英文版をつくって年に一度でも 二度でもいいから, 出版するということが必要 ではないかと痛感して㧍ります。そして外国の 大学図書館と相互交換するのです.

\section{技術革新時代に即応した体質改善を}

それからもう一つ，国家的見地に立ってのプ ランニングとか, リサーチの問題なんですけれ ども，これは医者との協力, あるいはエンジニ ヤリングを専攻している理工学部の人たちこう いう人たちとやはり連繫して，ぜひ十分金を使 ってその金がどこから出るかということは, 次 の問題になりますけれども，十分金を使って試 作するなりシュミレートしていくなりして，そ うしてやはり技術革新時代に即応寸る体制を立 てないと，国際競争から落伍するだけになる。 そういう面が医科器械の業界にある。私も微力 ではありますけれども，協力したいと思います けれども，何しろ金の問題がありますので，こ の金の問題をどうするか. 医科器械学会が財源 を持って，そこにある程度指導性を持つのが， あるいは各大学の研究機関や研究所があります が, その研究所に積極的に働きかけて研究委託 するのか，あるいはメーカが金を出して協同開 発するのか.とにかく開発をシステムエンジニ アの面からもっと積極的に行なわ扎てもいいだ ろう。放って扔ります。

3 番目に，先ほどの時閒にきびしい外国式に しなければいかんという，職人気質の問題があ りましたけれども，これは抢っしやると抢り で，パキスタンの鋼製手術器械などまだ多少な りとも手内職的にやって，人件費も安いという こともあって，初めのうちは日本との比較でそ う大したことはないだろう，太刀打ちできるだ ろうと思って抢ったものが，この数年で非常に りっぱなものになって，スウェーデンの鋼製器 械か，あるいはパキスタンのものかわからない
ようなものが事実ありますね。で，パキスタン のものを入手して，いま使って扮りますけれど も, 主としてさびの問題だとか, 構造・耐久 性，そういうものもチェックしているのですけ れども，なかなかすぐれて扮ります。こ礼残 念ながら非常にすぐれている，そのすぐれてい る点というのは，日本の製品と比べた場合に， 必ずしもすぐれているといえない面と，逆にす ぐれているという面と両方ありまして，いまの ところ私は五分五分の勝負と見ているわけで す.もしも輸入品の方が值段が安いとなると， かなり大きな問題になると思います，パキスタ ンの場合と同様の製品が韓国や台湾で行なわれ ると，わが国の業界に大きな影響を与えるでし よう。したがって，職人気質というようなもの に低迷しているようで注だめなんで，そういう 製造面の技術革新時代に即応寸る体質改善が業 界にとって必要であろうと私は思います。

笑い話ですけれども，先ほど問屋無用論が出 たのですが，小売りの店でこういう面白い話が あります。会津の方から私のところに突然見知 ら奴人があらわれて, 麻醉器というのはどうい うものかということから始まりまして，1時間 ばかりずっ前後 2 回にわたって聞きにきた人が いるのですけれども，かなり大きな東北地方の 病院に麻醉器械を一括して納めるということに なったらしいのです. しかし，そのディーラは 麻酔器の保守というのは，まずできそうにもな い，知識をもたない，それから気管チューブと いうものが子供と大人で太さが違うということ も全くご存じなかったようだし，そういうこと でイロ八から教えたのですけれども，その病院 にはこの程度の知識の者から買うといらことは 問題を残すけれども，どうかということをいっ たのですが，契約を結んでしまったということ です叔，そこで止むをえず，ある程度サゼスシ ヨンをしまして，しかもきびしい条件をつける ようにと教えたことがあるのですけれども，こ らいうようなディーラがまだいるのですね. 医 者のほうも, 認識不足のために，かなり大きな 犠牲を払わなけ机ばならないということが目に 見えているのです.

したがって問屋無用論の前に, こういう小売 
りの問屋が一つ立ちはだかっているということ に注目したい。これは東京とか大阪とかの大都 市の場合には，そういうことは扔のずからまあ 解消されると思いますけれども, 地方に行きま すと，まだまだ問題が残っていそうな気がいた します。ですからディーラとメ一カの間の大き な差が問題ですね. それはさっき言った保守契 約の問題にもちょっとからまるのですけれど も，保守をするのがセールスエンジニヤなの か，あるいはエンジニヤなのかといら問題を，

もうちょっとはっきりさせないと，保守契約と いう問題を具体的につかむことができないだろ うと思っているのです。，ということは器械の外 観はわかっているけ机ども，中はわからないと いらセールスエンジニヤが，どこが修理が必要 かということを断定することはいへん危険だと 私ども思いますし，したがって，その保守契約 の面でも，そういうセールスエンジニヤとか， あるいはエンジニヤといら差をきちんときめ て，そういう体制を整えた上で保守契約をきち んとやるということが望ましいので注ないかと 思ったわ括だ。

\section{保守契約について}

次に保等契約の問題になるのですけれども， これはやはり前近代的なやり方で, 無料サービ スということに依存してきたきらいがありまし たけれども，心電図が販売されたときに，一つ のエピソードがあります。心電図を読める専門 の医者が少ないときの話ですが，心電計のメ一 カもずいぶん多くなったし器械も売れた。 その とき開業医にぜひ普及させたいということで， それで心電図を読める医者に心電図をつくるメ 一カやディーラが解読をたのんだわけです。一 定期間単位で開業医を回って歩くわけですね. その間に患者のとりだめをやるわけです。ディ 一ラは，その解読結果をつけて送り返すという ようなことをサービスして，そうして心電計を 売りさぼいたといら時期があったわけです。つ い最近まであったわけです、いま若干脳波がそ れに近いことをやって扔ります。こういった分 業化といらことが医学の領域ではさかんでござ いますので，ですから記録計やグラフのこまか
い認識，あるいはその記録結果を專門家が見 てそそれチェックし直す，チェックするとい うことは私はいいことだと思いますけれども， 逆な面から言いますと, このやり方が心電図を 普及するのに一役買ったことは否めないでしょ う。それと似たようなことが，たとえば保守契 約の問題につながりますね. 故障がどこに起こ って，そいつが大体この辺だなあということが わかっても，一体それが何日間で修理が済むと か, そういう具体的な線がその場で出るかどう か, その器械が毎日回転している器械であると 非常に大きな口スになるわけです称，それから 保守の必要な重要性の意味でも病院診療の上で 直接の口スになるので，したがって，この保守 契約はやはりユーザ側の認識不足ということを 是正することが第一で, それからメーカの保守 契約の上でセールスマンがやるか，あるいは土 ンジニヤがやるかを，注っきりきめて体制をつ くっておいていただきたい.

第 3 の問題なんですが, 保守契約で必要なの は故障はどこか，拉よその判断をユーザがやる といら線に近づける努力をメ一カやディーラが するといらのは，非常にアイデアルである。し たがって，インストラクション・ブックという ものをもっと重要視していただきたい．しかも わかりやすいものにする，先ほどユーザ指導の お話がありましたけれども，医者は黙って耳に 入机てしまって，ノートもしない，そして忘れ るあるいはノートして扔る先生やナースも扔ら れるということなんですけれども，インストラ クション・ブックというものをもっと本格的な ものにつくりかえる必要がある. 欧米のものを ごらんになってわかると思いますけれども，こ れ注非常に詳細をきわめています. 保守の仕 方, それから日常の点検の仕方, それから絶対 にやってはならないということを禁忌としてち やんと書いてあります、これをやはり日本でも 大いにま放ていただいて，そうして少し金をか けていただく、そうして確実な内容にもらろん していただきたいといらことが，か祄てからの お願いなのであります。

ですから皆さん方のご意見とほとんど輻湊し た形になりますけれども，1970年代の医科器械 
学会というの注，非常に脱皮しなければならな い面がたくさんあって，そうして1960年来のア 力を落としながら，新しい技術革新に即応する 体制をいち早く立てなければならない，そうい うことに尽きるのではないかという感じがいた しております。

\section{0 年代に期待するもの}

市河 たいんんありがとうございました. をら司会の必要がないくらいにまとめていただ いて，論理的に明快にご説明いただいたのです が，最後に，もう時間がほとんど過ぎてしまい ましたけれども，それぞれの拉立場で，いろい ろメーカ・サイド，ディーラ・サイド，また輸 出とか, そらいう面からご発言を願いたいと存 じます。

この医科器械というものが70年代には，ライ フ・サイエンスという意味で, 成長産業になる であ万らということがよくいわ机ているわけで すが，私汢必ずしもこれがわれわれの医科器械 を指寸ものなのか，まだ疑問には思っておりま すけれども，いずれにせよ，生命をささえる機 器を生産し，販売していく企業として非常に注 目されている業界ではないか，こういうように 思うので，大きな目で見た見方，それからまた 社内的にもいろいろなその年代の断絶といらよ うなことで苦労されているマネージメントの問 題, それからまた一力には, 非常に前時代的な 生産形態の問題，いろいろ抱えていることが, さっき古橋先生の㧍言葉にもありましたよう に，この業界の70年代というのは希望にみちあ ふれるとともに，非常に削りしろが多いという ように感じられるのですけれども，その辺でひ とつ，一誩ずつ，松本さんから括を簡単にし ていただけませんでしょうか.

松本一言といわれるのですが，ちょっとつ け加えてもよろしいですか. 私, 一番最初に発 言させていただいたので，あと皆さん方のいろ いろご意見を伺って非常に参考になりましたの ですが，その中の幾つかについて，その時々に 感じたことがありますので，ちょっと話をさせ ていただきたい上思います。

\section{新しい販売・保安機構 $\odot$}

まず第一に，いま市河さんから，70 年代の われわ机の業界というか, 産業は非常に発展寸 る云々という括話がありました。私は去年でし たか, ニューヨークにコーネル大学といら大学 がありますが，あそこのプロフェッサーから， 1970年代には，いわゆる医療産業というのは， 世界の最成長産業の一つになるであるらという ことを耳にしたことがあります。そのとき感じ たことは，いわゆるわれわれの医科器械だけで なくて，先ほどふれたようにいろいろな $\mathrm{ME}$, あるいは光学関係の医科器械も含めて, またデ イスポーザブル製品も，ますます進歩していく といらことになると, 当然材料である高分子関 係の材料メ一カも入ってくるでしょうし，ある いは非常に高度にオートメ化された器械になれ ば，たとえばベルトコンベアのメ一カであると か，そういうようなメ一カも包含されるでし上 うし，いろいろと広い意味で医療産業といわ礼 るのでしょうが，いずれにしてもこの関倸の産 業といらのは非常に進んでいくことと思いま す。まあ, いわ沛る医科器械とそれに付随した ものをつくり，あるいは扱っておりますわれわ れとしても，そのような方向にはおくれないよ うにと，せめてそういう波に乗りおく机ない上 らに努力していきたい。亦た，そうすればそれ だけの恩恵もこうむるのではないかといらよう 汇考光ます。

そ机はそれとしまして，先ほどの西条さんの 㧍話にも，あるいはいまの古橋先生の抢話の中 にも「問屋無用論」がでてきて，先ほど私が口 走った言葉を採り上げられたのですが，先ほど の西条さんの属しておられる北海道の武藤器械 店さんの場合には，私の見るところでは, 全国 のこの業界でも有数のといえるほど，いわゆる 技術者を養成されて，技術的にしっかりしたデ イーラではないかと思いますので，そういう意 味で，だんだんそらいうようなディーラがふえ ていけば別に問題ないわけです，また小売屋さ んにしても，あるいは卸屋にしても，そのよう な技術力を備えたディーラばかりが多数々ろっ ていけばいいんだろうとは思うのですが，なか なか一朝一夕にはそうもいかないということも 
あると思います。ただ，いずれにしても先ほど 勝崎さんの言われたように，日本の国情という か, そういうことも考えていくと, 決して卸屋 なり，小売り屋なりがまるっきりなくなってし まうわけでもないでしょうし，また逆にわれわ れ医科器械のメ一カが全て肩代りして, 直売で 押し通す体制をとることも，あまり賢明とはい えないでしょう。したがって，国情からおしは かると，やはりそういうユーザ，メーカ，ディ ーラが一体となった販売機構というか, あるい は一つの組織というむのを考えていったほうが 進歩・発展のために有益だという感じはするの ですが，その場合一番最初に市河さんが，欧米 諸国では病院側が非常に業者に紳士的で, 対等 に接してくれるというようなお話をされたこと を思い出します. 確かにそうだと思うし, 今後 日本でもそうありたいと思うのですが，ただそ れにつけても先ほどのディーラ・サイド，ある いはメーカ・サイドでもより一生懸命に勉強す るというか，そういう努力を意らないというこ とで，やることをやってこそ両方が対等になる ので，口先だけで対等になりたいと言っても， なかなかむずかしい問題もあるのではないかと 思います。そういった意味で, この業界の商売 が，よく世間から一般に非常に保守的であると いうことも言われるのですが，いい意味の人的 な、コネクションによって商売が行なわれるな らいいんですが，いわゆる日本的な，あまりに 浪花節的な人間関倸による商売というものは, むしろ何というか，ユーザ・サイドと，それか ら販売側とを，むしろ対等ではない方向に持っ ていく傾向にあるので沈ないかいう気がし て，われわれますます努力をしていかなければ ならないのではないかと感じます。

先ほど古橋先生から，有償保守契約の件で, いわゆるセールスエンジニヤであるか, あるい はエンジニヤであるかというお話があったので すが，確かに扔っしゃると抢りだと思います。 たとえば，われわれが地方で耳にする場合に も，たとえばメ一カの工場実習なり技術講習な りに地方の業者さんが参加される，そうすると 非常に熱心にマスターして帰られても, 今度実 際にアフターサービスなりに行かれると，何か
メーカの人間がこないと，打金を払うのがもっ たいないような気がする，あるいはほんとうに 大丈夫かいなあという顔をされるといらような ことも, 実際にディーラの側ではあるようで す.そういったような意味で, なかなか解決が むずかしければ，これは1例ですけれども，有 償保守契約の中でメ一カがやる場合と，それか らディーラがやる場合とで料率を変えるという ことも一つの解決方法ではないかという気もす るのです.

\section{輸出について○}

それから先ほどの，これは東南アジアだけで はないかもしれませんが，日本の粗悪品が出て いるという点, これも確かに市河さんのいわれ るように, われわれ非常に海外に出ると, とく に愛国心からというわけでなくても，日常商売 上ではライバルのメーカの商品であっても, 外 国に出て，もしそこのクレームをいわれると， ついむきになって弁護してしまうということも 多々あります，ただ従来，確かに粗悪品という か，そういうものが出てしまったと一これれは いわゆる一流メーカ品でなかったかもしれませ んが，出てしまったとすれば，それは結局サプ ライヤーが何も知らないで出してしまった. 何 も知らないというよりも結局, 少しでも利幅が 多いものを出そうということからかもしれませ ん. そうすると結局, 安かろう悪からうという ものに通じてしまうのではないか, そういった 意味からも輸出検査基準なり何なり，いま医科 器械は, いわゆる強制検査品目ではないと思う のですが，（たとえげ光学顕微鏡なんかの場合 には, 強制検査品目です）そうでなくても業界 として自発的に，たと任意検查品目であって も, 必ず一定額以上の商品を輸出する場合に は，何というか公けの機関の輸出検査を受ける というような申し合わせをするとかいうような ことで，一歩一歩前進すべきだと感じます。

それから東南アジアにいった製品がさびてし まうという例ですけれども，乙れ注私，つい数 カ月前に私どものほうの社員で東南アジアに出 張した者が，たまたま他社製品でそういうクレ 一ムをつけられました、そのクレームをつけら れた鋼製小物が，日本では，いまでは一流メ一 
カのものといわ狄る品物であったので，意外に も感じたのですけれども，これはやはり湿度で あるとか，そういう気象条件なんかもいるいろ 研究する必要があるのか, あるいは材料的に研 究する必要があるのか，よくわかりませんが， 先ほど古橋先生の括話で，パキスタンのものは 十分に日本に持ってきても耐えていると，そう すると東南アジアのパキスタン，あるいはイン ド，インドネシアあたりでも，十分耐えている とすれば，これはやはり気象条件といったもの を日本でも輸出する場合十二分に考える必要が あるのではないか，私はよくわかりませんが， そんなような感じを抱きました。

鋼製小物について

それからもら一つ, 私, 先ほどオートメーシ ョンであるとか省力化であるとか, 非常に大き なことを言ったのですが，ひるがえって何とい うか，いままでのいわ沛る医科器械の重要性を 再認識する必要があるのではないかと思いま す。これは，たとえば自動監視装置というよう な非常に進んだものができてくる.あるいはオ ートアナライザにしてもそうですが，そういう ものがどんどん出てきても，明治時代以来の医 科器械，あるいは鋼製小物というものは決して なくなってはいかないものではないか，お医者 さんの手がなくして，器械だけでは手術はでき ないだろうというようなことから，やはり鋼製 小物一つとっても, 従来の医科器械の改良につ いても，ますますメーカ・サイドとして努力を しなければいけないのではないかと思います。

これはただ鋼製小物が人件費の值上がりのため に值上げをどんどんせざるをえないというよう なことで，やはり代替品に負けてしまう場合も ありましょうし，そのいい例が，最近盛んに輸 入されている替刃のメスですか, ああいったも のに代表されるので流ないかという気もするの ですが，そういうようなことをいろいろ感じま した.

そ扎からもうつ，これはユーザというより も厚生省あたりに要求することかもしれません けれども，いかにわれわれメ一カ・サイドで共 同開発をしていい器械を生み出しても, 結局, 多くの病院側に予算がない（もちろん例外も
ありますが）そのためにアメりカでは非常によ く使われる，あるいは便利だということになっ ても，日本の病院では予算面から使いこなせな いというか, 購入できない, 特定の病院を除い ては，关ういうような例があると，非常にわれ われメーカ・サイド, ディーラ・サイドにとっ ても淋しい気がするので, 決して省力化, ある いはオートメーションの器械といっても, 全く の無人で動く機械というものは非常に少ないの ではないかと思いますし，そういうような意味 で，やはりそれなりの人件費の予算も必要だ， そういう気がするわけです。

\section{イミテーションについて}

それから先ほどのイミテーションというか, コビーという問題ですが，これも確かに扔説の と掞りだと思います，ただ場合によると今後と も出てくると思うのですが, 先ほど市河さんの お話のように，外来の学問であるだけに当然の 宿命として, 向こうのメ一カを何らかの形で知 る.これは打医者さんの紹介により，あるいは パンフレットで知ろらが，今後とくに’70 年代 あたりから日本のメーカが向こうのメーカに一 定のロイヤリティーといらか, 技術使用料を払 って，正々堂々とつくるという形がだんだんふ えてくるのではないか。これはいままでもあっ たことと思いますが，私どもの場合でもそうい うケースがあります。ただ，そのことがたまた ま公表されないと，ただのものま枚ではないか というょうに誤解される場合もあるでしょう し，これはいろいろなケースがあるだろうと想 像します、いず机しても今後そういらような いわ收るビジネスライクな関係がふえてくるの ではないか。そうしたならば，今度は国内のメ 一カ相互間でも，一定の技術使用料を払って， 正々堂々と，いいものは別に，他のメ一カでも 部分的につくってもいいのではないかというこ とが，将来はだんだん出てくるかもしれません が，これは夢というよりも，そうありたいとい うことではないでしょうか，そのように感じま した。

\section{規格化について}

それから最後に規格化ということですが、こ れも確かに感じます。で，規格化ということで 
器械の規格化, 三れから私は用語の統一化とい らか，それぞれの器械に使っている用語，ある い:滅菌法研究会でいま問題になっているよう な滅菌基準の規格化といらか，標準化，それか らていては，それぞれのたとえば 50 ベッド， 100 ベッド，500ベッドというようなベッド数に 応じた病院の設備, あるいは什器, 備品類の標 準化といらか，そういうようなことにまで及ん で 70 年代とす扎ば，そういうものの一定のリ ストが医科器械学会なり何らかの機関で作成さ れてほしいというように，いろいろの意味の規 格化がほしいと思います。それれつけても，こ の前の予算では流れてしまったよらですけれど も，厚生省で考光ら机ている国立医療技術研究 所みたいなものがソ連と同じょうな形で日本に もできたならばいいんではないかというような ことを考えるわけです。

70 年代にはこういう器械ができるのではな いかとか，あるいはできてほしいという希望も 㐫りますが，西まり私一人だけ時間をとっても 申しわけないので，この辺でやめておきたいと 思います。

市河たいいんありがとらございました。い まの扮話，まことに一々耳を傾けさせていただ いた次第です，最後に打っしやった規格化の問 題で, 学会ではおそらく近々に, 学術部のほう で提唱されて扔りますので，いわゆるベッド数 に灾じた一つの機器のスタンダーダイゼーショ ンというむのが採り上げられるだろうと思いま すし（注：現在すでに病院設備基準特別委員会 で進行中)，松本さんの予測されるような 70 年 代の姿というものは，おそらく相当の確率で期 待されるのではないか，こう思います。

安定よりも成長を ○

私，あまり司会が上手でないので，ご発言の 時間がほとんどなくなってしまいましたけれど も，打気づきのことをほとうの要点でけっこ うですから，それぞれご発言をいただきたいと 思うのですが，勝崎さんひとつ.

勝崎 希望的なことなんですけれども，他の 業界からいわせますと，医療業界というのは安 定産業であるというようなことをいわれておる のですが，安定産業ではない，成長産業である
と説明しておりますが，言葉だけの，また紙上 だけの成長産業でなく，真の成長産業に持って いかなければならない，その成長産業に持って いくがために，いわゆる「セールス」，それか らまた「セールスエンジニヤ」だけというので なくて，「セールスエンジニヤ プラス セー ルスコンサルタント」というような考え方をも って活動しなければいけないのではないか，ま た1970年代はそのような方法で活動したいと思 っております。

市河 ありがとうございました，青木さんい かがでしょう。

青木 これは，われわれのやらなければなら ないことであり，宿命的なものなんですけれど も，やはり最終的にはいいものをつくり，才リ ジナリティを持ったものをつくって，日本だけ でなくて外国にもどんどん輸出していく。こう いら気持でやらなければならないと思います。 それにはわ机れメーカとしても，いろいろな 開発をする，それには政符関係のほうからも， できたら研究所みたいなものをつくっていただ き，その研究所で基礎的な研究をしてもらっ て，いい器械を輸出していけるようになればい いと思います。

市河 ありがとうございました。いまの最後 のお言葉，私，声を大にして厚生省側に伝わ机 汭と思いますが，とくに厚生省という立場では 医療産業といいますか, 上くに医科器械の産業 に関して保護育成の義務があると思うのです。 その義務を何とか 70 年代に注，ほんのわずか でもいいから果たしていただきたい。

これは薬事法の問題も含め，安全基準の問題 も含め，またいま括話のったような総合研究 所のようなもの，もしくはそういうェンジニヤ リングの一つの確立といいますか，エンジニヤ の養成，そういうところまで手が届けば，私な おさらけっこうと思いますけれども，その第一 歩として 70 年代には，ぜひ厚生省にそういら 立場でのあたたかい指導・育成ということにひ とつ目を向けていただきたいと思います。そ礼 では，根本さんにひさつ。

根本 同じょうなことですけれども，われわ れとしては独自の製品の開発研究に努力し，日 
本はもとより世界中どこの先生方にも安心して 使っていただけるようなものをつくっていきた いと思って抢ります。

市河 ありがとうございました。ただいまの お話もおそらくコンペティター同士の協業化と いう問題にも相通ずるのではないかと思います が，これはドイツあたりではどんどんやられて おりますし，日本でも，ただいたずらに，おれ さえもうけ礼流いいという立場の寄り集まりで は招そらくこの業界は，もはや70 年代は自滅 する方向に進むのではないかと思います，それ では, 西条さん……

\section{ユーザのニードを早く知れ}

西条 ユーザである先生方は何を求めている かといらことをわれわれがよく認識して，真の アフターサービスといらものをこれから提供し ていこうと，无う考えております。

市河 ありがとうございました。われわれの 企業の目標というのは，要するにユーザの二ー ドを早くキャッチして，それに少しでも満足の いくような経営をしていくというのが根本でご ざいますから，扔っしるとおりだと思いま す．それでは神野さん，最後にひとつ。

神野 私が最後になりましたが，わが国は小 さい島国で資源にそしくまた人口密度が非常に 高いという特徵を持っています，原料はどうし ても諸外国の輸入に頼らなければなりません が，製品を加工・製作するといら日本人特有の 手先の器用さを生かした技術や工業力を活用す ることは人口密度の点からみても非常に有利で あると思います。そこで私たちとしましては， エンド・ニーザの要求を充分に満たした技術的
に優れた製品を開発していくことが日本の医療 器業界の宿命であると考えております。この場 合, ユーザの要求が単に一権威者やまた一メ一 カ・サイドの専門家のみの考えだけで決めら礼 た偏ったものでなく，エンド・ユーザであるド クターやナースまたディーラ，およびメーカの 関係者で充分討議されて得られた真の意味のエ ンド・ユーザの要求を指すわけでございます。 こういうことは，一朝一夕にして出来得るもの でなく次第に積从重致ていって完成されて行く ものと思います。こういうことが激しい国際競 争に打ち勝っていくための礎となるのではない かと思います。その意味からも諸先輩の方々が 築いてくださった貴重な地盤を無䭾にせず， そ れをもとにしてわれわれの努力によって1970年 代の発展を期待したいと思います.

市河 たいへん時間がオーバーしてしまいま したので，まだまだ幾らでも皆さんに打話をい ただきたい気持ちは十分にございますのです が，いかんせん司会のまずさからこのように時 間がなくなってしまいましたので，本日はこの 辺で打ち切らせていただきますが，ひとつ皆さ ん方を介しまして，同年代の方々にもぜひ，ひ とつそういう捜気持ちを呼びかけていただい て，この業界の発展と，それからまた，この医 科器械学会に対する認識をますます強めていた だきまして，70 年代にはぜひ皆さんが㧍考え になっているようないろいろな期待を少しでき 多く実現させていきたいものだと，こういうよ らに思います。

きょうはほんとうに执忙しいところ，ありが とうございました。 